\title{
LIFE CYCLE ASSESSMENT IN THE FOOD SUPPLY CHAIN: A CASE STUDY
}

\author{
David McCarthy ${ }^{\mathrm{a}}$, Aristides Matopoulos ${ }^{\mathrm{b} *}$ and Philip Davies ${ }^{\mathrm{c}}$ \\ ${ }^{a}$ Faccenda Group Ltd, Hortonwood, Telford, UK; ${ }^{b}$ Engineering Systems \& Management \\ Group, School of Engineering \& Applied Science, Aston University, Aston Triangle, \\ Birmingham, UK; ${ }^{c}$ Sustainable Environment Research Group, School of Engineering \& \\ Applied Science, Aston University, Aston Triangle, Birmingham, UK
}

\begin{abstract}
This research aims at assessing the environmental impact of the poultry supply chain from cradle to grave using case study research and also life cycle assessment (LCA). While a limited number of generic poultry production LCA studies have been published, fewer yet assess the whole process of a specific organisation, none comparing the increased impact of further processing. Our results show that irrespec- tively of the impact assessment method utilised, the process of producing portions is considerably higher in total environmental impact due to the extra raw material required to produce the same mass into retail. Our research contributes to the growing number of LCA studies and could be used by practitioners for comparison against national and international averages. From a theoretical point of view, this research provides new insights into the relationship between vertically integrated supply chains and environmental performance which has not been examined in the past.
\end{abstract}

Keywords: cradle-to-grave; life cycle assessment; food supply chain; transport; environmental impact; vertical integration

To cite this article: David McCarthy, Aristides Matopoulos \& Philip Davies (2015): Life cycle assessment in the food supply chain: a case study, International Journal of Logistics Research and Applications: A Leading Journal of Supply Chain Management, DOI: $10.1080 / 13675567.2014 .997197$

\section{Introduction}

In the agri-food sector, acknowledging sustainability pressures is extremely important as agri-food supply chains are more global than ever and are characterised by increased imports and exports and global sourcing of products (WTO 2009; Wognum et al. 2011). The sector is, by definition, an intensive resource-use one and its impact upon the sustainability and resources cannot be ignored. This is particularly the case in Europe, where the European food sector is the largest manufacturing sector, transforming $70 \%$ of EU's agricultural raw materials, while also employing over four million people, the majority in SMEs (FoodDrinkEurope 2012a). The agricultural and the food sector are two very interdependent sectors with the first one ensuring that affordable food can be mass produced with often limited and scarce resources while accommodating an expanding population alongside ever increasing raw materials prices. This has resulted in a food industry which is one of the major contributors to the UK economy with a 
projected 2014 retail food market value of $£ 168$ billion, placing it within the top 10 largest markets in the world (Neves 2011). For both sectors, expectations and concerns over the efficient use of resources are growing. It is not just consumers, governments, policy-makers, producers and retailers that are becoming increasingly conscious of where and how food products are produced, and of the amount of resources (i.e. energy, water, materials) used during the product's life cycle. The food industry aims at achieving 100\% usage of agricultural resources and full valorisation of its by-products. Nevertheless, estimates indicate a total of 90 million tonnes of food wasted annually at the EU level, representing $179 \mathrm{~kg}$ per capita (FoodDrinkEurope 2012b). According to FAO (2011) food waste and losses are generated across food supply chains within five system boundaries: agricultural production (e.g. losses due to mechanical damage and/or spillage during harvest operation), post-harvest handling and storage (e.g. losses during storage and transportation between farm and distribution), processing (e.g. including losses due to spillage and degradation during industrial processing), distribution (e.g. due to losses and waste at the wholesale markets, supermarkets, or retailers) and at consumption (e.g. due to reaching the expiry date).

Pressures on resources are increasing and if current trends continue in respect of the growth of the global population, the more intensive use of the world's resources will put pressure on the planet, threatening the security of supply (European Commission 2011). In the UK, by 2035, the population is estimated to reach 73.2 million (ONS 2011). This significant increase in population will clearly require an equally significant increase in food production whether locally produced or imported. The scale of the food production industry and the increasing demands upon it are important factors to consider when assessing its environmental impact. More significantly, Sonesson, Berlin, and Ziegler (2010) suggest that by 2050, there will be a doubling of the consumption of animal products globally. This will create great challenges for stakeholders in finding innovative ideas to reduce nutrient losses from the food chain while improving sustainability; these challenges are particularly poignant for large-scale agribusinesses. In this research, we examine the integrated supply chain of a major UK chicken producer and we assess its environmental performance using life cycle assessment (LCA). As Yakovleva and Flynn (2004) argue, chicken makes a particularly good case study with which to explore sustainability and supply chain management implication. 
We focus on poultry which is an important sub-sector of the meat market in UK with a total retail value of $£ 4$ billion every year (BPC 2013). In comparison with other livestock, broiler chicken production is comparatively efficient; but still, according to several studies, there is great scope for improvement (Williams, Audsley, and Sandars 2006; Rabobank 2012). The overall aim of this paper is to establish the environmental impact of the chicken supply chain from cradle to grave, specifically the cradle-to-gate process. Using a cradle-to-grave approach across a range of environmental impact assessments, we compare two different production scenarios: Whole Birds and Portions Operations.

We also explore the comparative impact of a range of transportation methods utilised across the supply chain. In terms of structure, the paper continues with the literature review and continues with the methodology section where the description of the research process is provided. Next, the results of the LCA are presented. We conclude the paper with a discussion of the findings and the conclusion.

\section{Literature review}

The last years have seen an ever increasing focus, appreciation and necessity in considering the impact that consumer products, particularly food, have on the environment (Virtanen et al. 2011). There is now a universal scientific consensus that human activity has a direct link with climate change (Tan, Tan, and Khoo 2012), and this is just one of many reasons that the food industry as a whole is taking a more proactive approach to examining their own environmental impact. In the first world, there is a constantly growing awareness that present food and resource consumption habits are neither sustainable nor healthy (Andersson 2000). The food industry has a considerable impact due to the agricultural base of the production processes which are using water resources and energy, and emit greenhouse gases (Harris and Narayanaswamy 2009). For example, Nemetz (2007) writes that as much as 500,000 tonnes of active ingredients are applied to crops worldwide each year, causing significant eutrophication in addition to climate change impact. According to the Food and Agricultural Organisation (UN), the three most common greenhouse gases $\left(\mathrm{CO}_{2}, \mathrm{CH}_{4}\right.$ and $\left.\mathrm{N}_{2} \mathrm{O}\right)$, with $9 \%$ of all anthropogenic $\mathrm{CO}_{2}, 37 \%$ of anthropogenic $\mathrm{CH}_{4}$ and $65 \%$ of $\mathrm{N}_{2} \mathrm{O}$ emissions, are directly generated by livestock (FAO2006). 
With a biological production cycle of five months and a narrow genetic base, the poultry sector is a fast-moving mass-production one (Ward 1997). Hatching and growing are the two primary production processes, apart from the processing and distribution stages which are common to other meat-producing sectors. The sector is also heavily reliant on the agricultural processes that contribute to feed production which contributes nearly half (47.2\%) of GHG emissions, followed by chicken production (27.6\%), transport (18.1\%) and meat processing (7.2\%) (Tan, Tan, and Khoo 2012). Considerable research has been done in the sector during the last years with regard to the environmental implications of poultry production and in the following paragraphs, a discussion of relevant research is presented.

All poultry-specific LCA studies, with the exception of Kist, Moutaqi, and Machado (2009) directly compare a functional unit while analysing a comparison of various production processes or techniques. The Kist, Moutaqi, and Machado (2009) paper interestingly utilised LCA to highlight environmental impact on a sector-by-sector basis and examining inefficiencies in water treatment plant. In contrast, Tongpool et al. (2012) focussed their LCA on the environmental performance of broiler feeds. This was undertaken as a 'cradle to gate' study and indeed, the number of the LCAs has been restricted to a 'cradle to gate' analysis. It is speculative to presume, but entirely plausible that this is not in small part owing to the less than satisfactory auxiliary databases available, unable to fully facilitate generic post production data requirements until developments in recent years. More advanced databases and the improvements made in each edition provide a greater accuracy in aggregate European auxiliary data provision. In his research, Tongpool et al. (2012) utilised an averaging method in order to aggregate the feed inventory (broilers are fed varying feed mixes in stages up until optimum kill weight). These data were also of a primary nature and collected directly on site at feed mills.

Bengtsson and Seddon (2012) in their extensive LCA of Australian fast food chicken, used many assumptions in the model to differentiate free range from standard broiler production. For example, adjusting feed based on half the mortality rate for free range birds without considering the non-linearity of consumption over growth. In attempting to measure the sustainability of different poultry production systems, Castellini et al. 
(2012) also utilised the Ecoinvent database alongside primary data directly from farms or literary sources. Although the study also considers social and economic performance of different farming systems, there is also detailed analysis of ranked and weighted environmental indicators. It is this application of several indicators that makes it a successful multi-criteria approach.

Where Bengtsson and Seddon (2012) examined systems producing fast food chicken, and Castellini took a multi-criteria approach to a similar investigation, Davis and Sonesson (2008) directly compared two chicken meals. This was an intriguing study as whole meals delivered to the table for the consumer were considered as a functional unit, one home-made, one semi-prepared. This is a similar concept to the 'breast packs vs. ready to cook packs' comparison, originally a consideration but found to be beyond the scope of this research. Again, there is great detail regarding the system boundaries (minor ingredients omitted) and a generally positive view of the data and sources in this instance, including databases and peer-reviewed literature.

It is clear that the standardisation through ISO 14040 series and the continued development of a methodology without compromising credibility have been important factors in establishing LCA as a leading environmental assessment model. We have seen that it is matters such as defining clear boundaries and setting explicit goals and scope that are vital in supporting a successful study. The selection of impact assessment methodology is critical in realising these goals and it is apparent that there is much more that can be learnt regarding this discipline. Although many studies utilise assumptions and external database banks to 'plug gaps' in primary data, it is with careful uncertainty mitigation and analysis that LCA can remain relevant. With diligence and attention to detail, it is evident from the literature that a properly executed LCA can be a productive and complementary tool for business in assessing their environmental impact either holistically, as a product development strategy or as a complementary business portfolio development tool. In Table 1, the key work done in this field is summarised. 
Table 1: Poultry based LCA studies

\begin{tabular}{|c|c|c|c|}
\hline Author & Title & Key Ideas & Stage \\
\hline $\begin{array}{l}\text { Bengtsson and } \\
\text { Seddon (2012) }\end{array}$ & $\begin{array}{l}\text { Cradle to Retailer or Quick } \\
\text { Service Restaurant Gate Life } \\
\text { Cycle Assessment of Chicken } \\
\text { Products in Australia }\end{array}$ & $\begin{array}{l}\text { Upstream feed production most } \\
\text { significant, then agriculture } \\
\text { followed by processing. Food } \\
\text { Conversion Efficiency } \\
\text { considered. }\end{array}$ & Cradle to retailer \\
\hline $\begin{array}{l}\text { Castellini et al. } \\
(2012)\end{array}$ & $\begin{array}{l}\text { A multi-criteria approach for } \\
\text { measuring the sustainability of } \\
\text { different poultry production } \\
\text { systems }\end{array}$ & $\begin{array}{l}\text { Sustainability of different } \\
\text { systems: conventional, organic } \\
\text { and organic 'plus'. Ecological } \\
\text { footprints, energy analysis }\end{array}$ & $\begin{array}{l}\text { Cradle to farm } \\
\text { gate }\end{array}$ \\
\hline $\begin{array}{l}\text { Davis and } \\
\text { Sonesson } \\
(2008)\end{array}$ & $\begin{array}{l}\text { Life cycle assessment of } \\
\text { integrated food chains-a } \\
\text { Swedish case study of two } \\
\text { chicken meals }\end{array}$ & $\begin{array}{l}\text { Complete meals used as } \\
\text { functional units. Consumer } \\
\text { transport and packaging } \\
\text { significant. }\end{array}$ & Cradle to grave \\
\hline $\begin{array}{l}\text { Katajajuuri et } \\
\text { al. (2008) }\end{array}$ & $\begin{array}{l}\text { Environmental impacts and } \\
\text { related options for improving the } \\
\text { chicken meat supply chain }\end{array}$ & $\begin{array}{l}\text { Finnish retail breast meat study. } \\
\text { Much lower impact than UK. }\end{array}$ & Cradle to gate \\
\hline $\begin{array}{l}\text { Leinonen et al. } \\
(2012)\end{array}$ & $\begin{array}{l}\text { Predicting the environmental } \\
\text { impacts of chicken systems in the } \\
\text { UK through a life cycle } \\
\text { assessment: Broiler production } \\
\text { systems }\end{array}$ & $\begin{array}{l}\text { UK LCA of systems: standard } \\
\text { indoor; free range; organic. Feed } \\
\text { production, processing and } \\
\text { transport highest impact. FR and } \\
\text { O highest. }\end{array}$ & Cradle to gate \\
\hline $\begin{array}{l}\text { Tongpool et al., } \\
\text { (2012) }\end{array}$ & $\begin{array}{l}\text { Improvement of the } \\
\text { environmental performance of } \\
\text { broiler feeds: a study via life } \\
\text { cycle assessment }\end{array}$ & $\begin{array}{l}\text { Animal-mixed and vegetarian } \\
\text { feeds investigation. Animal- } \\
\text { mixed was found to have lesser } \\
\text { impact due to increased maize } \\
\text { drying. }\end{array}$ & Cradle to gate \\
\hline $\begin{array}{l}\text { Williams et al. } \\
(2006)\end{array}$ & $\begin{array}{l}\text { Determining the environmental } \\
\text { burdens and resource use in the } \\
\text { production of agricultural and } \\
\text { horticultural commodities }\end{array}$ & $\begin{array}{l}\text { Evaluation of different } \\
\text { production systems in the UK: } \\
\text { indoor, free range, organic. Plus } \\
\text { range of agricultural } \\
\text { commodities. }\end{array}$ & $\begin{array}{l}\text { Cradle to farm } \\
\text { gate }\end{array}$ \\
\hline
\end{tabular}

One of the major issues that are highlighted from the review of the literature is that from all the reviewed articles, none has considered the role and impact of vertically integrated supply chains. Previous research (Sorrell et al. 2004; Delmas and Pekovic 2013) has suggested that firms in vertically integrated supply chains, with centralised decision-making, are more likely to adopt resource efficiency strategies and improve their environmental performance, but these arguments have not been supported by empirical data on actual environmental performance. In this paper, we try to increase knowledge and understanding in this field by providing empirical evidence.

\section{Methodology}

In this research, we adopted a single-case holistic design (Yin 2003). A single case study of a poultry processor supply chain was conducted in order to develop an in-depth understanding of the environmental performance of the entire supply chain. A single 
case design was deemed most appropriate because it allowed assessing the environmental impact of focal company's operations for its entire supply chain using LCA. The case was selected because it enabled accessing an extensive set of data across the entire supply chain. This is in line with Browne et al. $(\underline{2005}, 781)$ who have argued that: 'studying only part of the supply chain or only specific activities can lead to greater difficulties in terms of the acceptance of the results and their interpretation'.

LCA is a tool that may be used by stakeholders in the supply chain to assess environmental impacts and thus make better decisions with the aim of reducing these impacts. Ideally, a LCA study should examine all material and energy flows (i.e. the inventory) associated with the manufacture, use and disposal of a product to provide an all-encompassing view of the product life cycle 'from cradle to grave'. In the absence of this life cycle perspective, problem shifting may inadvertently occur, whereby attempts to reduce impacts in one phase of the life cycle increase impacts in another. LCA reduces the inventory data set, which is usually very large, into a much small number (typically $<10$ ) of quantified and relevant impact categories, thus allowing side-by-side comparisons of different products, processes or logistics. The quantified and rational approach of LCA is appealing, but there are also many critiques to this methodology; for example: (i) comprehensive inventory data are rarely accessible in practice, forcing assumptions which could invalidate the results; (ii) stakeholders carrying out LCA may therefore choose convenient assumptions, thus biasing outcomes towards predefined goals; (iii) aggregation of impacts and presentation of reduced data sets may conceal important local issues and later spark controversies if the LCA results are used to make decisions that create both winners and losers through environmental mechanisms. Moreover, LCA captures primarily the environmental dimension of sustainability, whereas social and certain ethical dimensions are much harder to quantify. So, in the context of food supply chains, a LCA study would not be a good tool with which to assess animal welfare. Further background and discussion of LCA methodology are found in Baumann and Tillman (2004).

This study considers the entire life cycle of a functional unit of $1000 \mathrm{~kg}$ of plain retail chicken both as trussed packed whole birds and as packed portions. A cradle-to-grave approach is undertaken, and includes the total contribution of processes used in each 
production system. It also addresses waste scenarios originating at each system and the consequential end-user waste scenario associated with packaging: both landfill and recycling. The method for generating such an assessment is through modelling the complex technical system for production, transportation and disposal of the functional unit. The life cycle inventory is the model of entire process input and outputs produced in the software and developed using a Bill of Activities and Unit Process data. The Bill of Activities includes materials, production requirements and transport tonne-kilometres for the production system. These are combined with unit process inventory data to construct the life cycle inventory. Industrial processing is an example of such an activity system. Unit process inventory data comprise the lowest level elements such as grid electricity mix or PET plastics for packaging production. Upstream processes such as the grid electric mix are obtained from unit inventory databases such as Ecoinvent (version 2.2) with minimal modification except with regard to altering location and transportation distances. In some instances, US or European scenarios are used although, where possible, UK-derived process data are used in preference.

\section{Functional unit}

The concept of a functional unit is important and is carefully considered in any LCA. In essence, each process must be compared equitably and relatively to the product assessed. ISO 14044 describes it as 'being consistent with the goal and scope of the study. One of the primary purposes of a functional unit is to provide a reference to which the input and output data are normalised (in a mathematical sense)' (ISO 2006). Therefore, the functional unit shall be clearly defined and measurable. Units such as price and Whole Bird equivalent are unsuitable owing to value and average size fluctuations, respectively. The functional unit is therefore established as $1000 \mathrm{~kg}$ of fresh, plain chicken; as packaged, delivered, consumed and disposed of by the end user.

\section{Company's supply chain description}

The focal company in this research is a vertically integrated chicken producer, rearing and processing upwards of 1.9 million birds per week. The business itself is vertically integrated and comprises company-owned operations ranging from rearing and feed milling, to industrial processing and distribution. Figure 1 outlines the top-level system process flow associated with production of chicken meat to the end consumer. In terms 
of production, the supply chain is described as three distinct systems: agriculture; breeding and rearing; and industrial processing. The system is vertically integrated with birds bred and slaughtered by the same company. Distribution and consumption systems are also included as the analysis represents the product life cycle. While the individual contributory elements of producing the diet are factored in the software model, the individual processing stages within both primary processing and portion operations are collated as aggregate Processing Processes. This is also the case with the three farming processes: breeder; layer; and broiler.

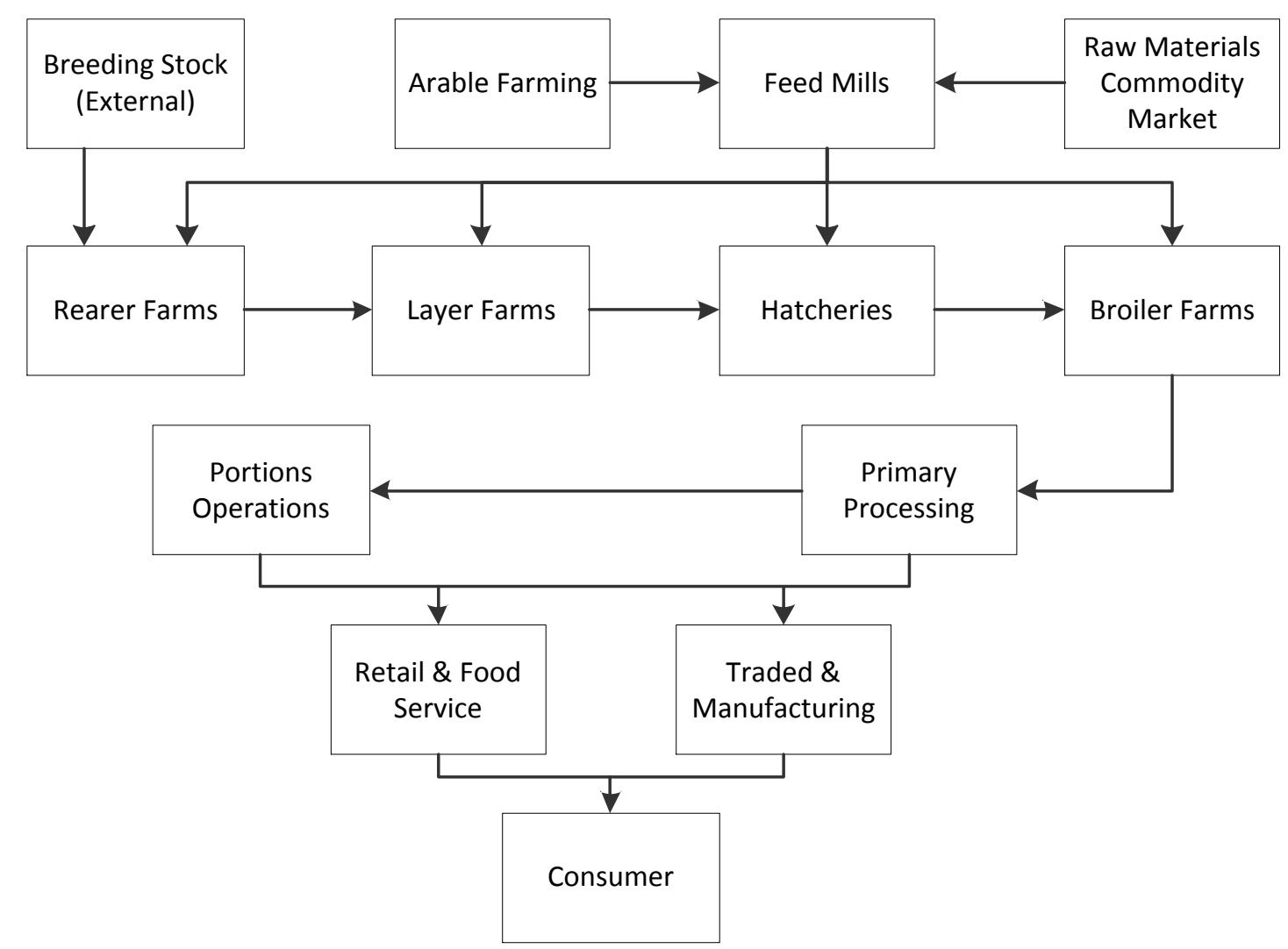

Figure 1: Overview of the production systems for company's vertically integrated supply chain

\section{System boundaries}

The literature thoroughly explores the implications of clearly defining system boundaries and the controversy surrounding these decisions. This study aims to take an 'attributional approach', attempting to account for as complete an assessment of the cradle-to-grave life cycle environmental impact of the functional unit as possible. Tillman (2010) analogises the concept well when suggesting that if the results of all the 
LCA studies of all the products in the world were multiplied with production volumes and added together, the sum should equal the total environmental impact of the entire world'. The question of boundary choices arises when considering factors such as the inclusion of capital goods. For the purpose of this study, capital goods such as factory machinery will not be included due to the negligible impact that can be established at an early stage. For example, the sum of the production and materials usage of a tray sealing machine (allocated over a 15-year life and across approximately 800 million WBE) would feature immaterially in the final impact assessment. It was beyond the scope of the study to extend primary data collection to these extremes regarding such an ineffectual benefit. That said, unit systems derived from databases and other LCAs will often include many associated processes.

\section{Data collection}

All primary data acquired were taken for the calendar year 2012 so as to account for seasonality when allocating to smaller units in the LCIA preparation phase. In total, 13 managers (or members of their teams) were interviewed in order to collate a data set representative of inputs and outputs at each system ready for preparation for the LCIA model. A large quantity of primary data was acquired from the business accountants. This involved meeting with finance managers from each supply chain system (Figure 2) and discussing the scope of the project and the compilation of the necessary data. Further data were acquired through meeting with planning and operations managers.

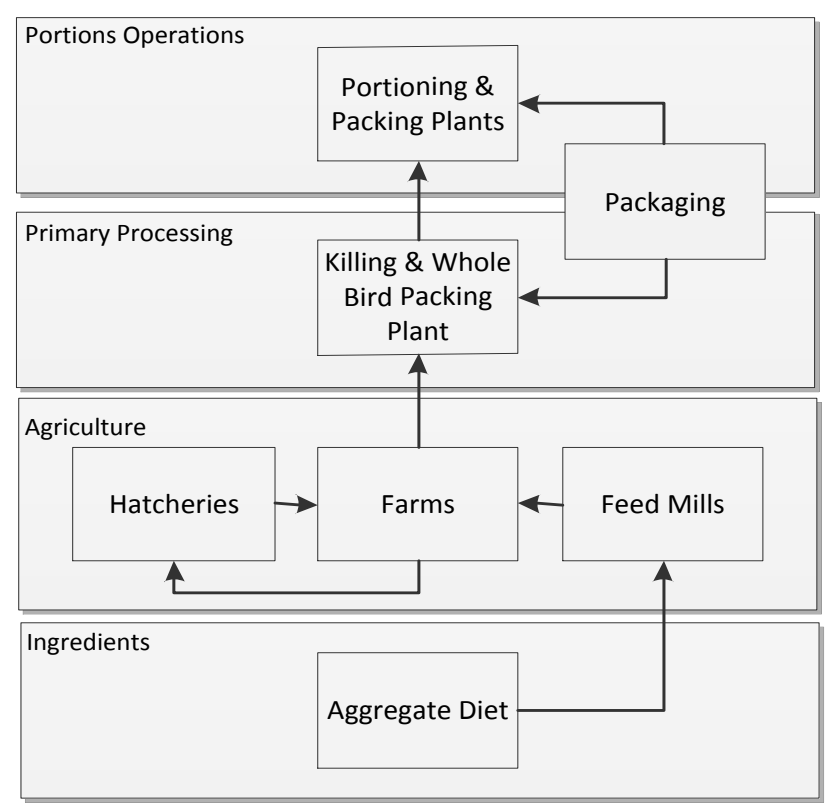


Figure 2. Primary data acquisition systems and associated processes

Table 2 shows the range of systems from which an extensive quantity of detailed primary data was sourced. These data then required a great deal of further processing (in Microsoft Excel) to accommodate the LCIA software model.

Table 2: Primary data acquisition systems, associated processes and personnel access requirements

\begin{tabular}{|c|c|c|c|}
\hline Position & System & Meetings & Correspondence \\
\hline General Manager & Breeder Division & $\begin{array}{l}\text { Facilities tour and } \\
\text { introductory discussion }\end{array}$ & Data enquiries by email \\
\hline Site Manager & Hatchery & $\begin{array}{l}\text { Facilities tour and data } \\
\text { requirements discussion }\end{array}$ & Data enquiries by email \\
\hline $\begin{array}{l}\text { Raw Materials } \\
\text { Manager }\end{array}$ & $\begin{array}{l}\text { Feed Mills \& } \\
\text { Ingredients }\end{array}$ & $\begin{array}{l}\text { Introductory discussion and } \\
\text { to establish requirements }\end{array}$ & Data enquiries by email \\
\hline $\begin{array}{l}\text { Senior Planning } \\
\text { Manager }\end{array}$ & Portions Operations & $\begin{array}{l}\text { Data preparation discussion } \\
\text { and checks }\end{array}$ & $\begin{array}{l}\text { Data enquiries by email \& } \\
\text { telephone }\end{array}$ \\
\hline Planning Manager & Portions Operations & $\mathrm{N} / \mathrm{A}$ & $\begin{array}{l}\text { Data enquiries by email \& } \\
\text { telephone }\end{array}$ \\
\hline $\begin{array}{l}\text { Agricultural Planning } \\
\text { Manager }\end{array}$ & Agricultural Planning & $\mathrm{N} / \mathrm{A}$ & $\begin{array}{l}\text { Data enquiries by email \& } \\
\text { telephone }\end{array}$ \\
\hline General Manager & Primary Processing & $\begin{array}{l}\text { Facilities tour \& discussion } \\
\text { to establish requirements }\end{array}$ & Data enquiries by email \\
\hline Finance Manager & Agriculture & $\begin{array}{l}\text { Introductory discussion } \\
\text { establishing requirements }\end{array}$ & N/A \\
\hline $\begin{array}{l}\text { Management } \\
\text { Accountant }\end{array}$ & Agriculture & $\begin{array}{l}\text { Introductory discussion } \\
\text { establishing requirements }\end{array}$ & $\begin{array}{l}\text { Data enquiries by email \& } \\
\text { telephone }\end{array}$ \\
\hline Finance Manager & Primary Processing & $\begin{array}{l}\text { Introductory discussion } \\
\text { establishing requirements }\end{array}$ & $\mathrm{N} / \mathrm{A}$ \\
\hline $\begin{array}{l}\text { Management } \\
\text { Accountant }\end{array}$ & Primary Processing & $\begin{array}{l}\text { Introductory discussion } \\
\text { establishing requirements }\end{array}$ & $\begin{array}{l}\text { Data enquiries by email \& } \\
\text { telephone }\end{array}$ \\
\hline Finance Manager & Portions Operations & $\begin{array}{l}\text { Data requirements and } \\
\text { acquisition }\end{array}$ & $\begin{array}{l}\text { Data enquiries by email \& } \\
\text { telephone }\end{array}$ \\
\hline Senior Buyer & $\begin{array}{l}\text { Purchasing } \\
\text { (Packaging) }\end{array}$ & $\begin{array}{l}\text { Data requirements and } \\
\text { acquisition }\end{array}$ & $\begin{array}{l}\text { Data enquiries by email } \& \\
\text { telephone }\end{array}$ \\
\hline
\end{tabular}

\section{Impact assessment methods used}

Interpretation of the inventory assembled is reliant on statistical analysis to produce impact assessments and comparison studies. These are in the form of methods of which a comprehensive range is available in the software used. The assessment methods utilised were the following: GWP 100a (Global Warming Potential over 100 years), CML 2001 (All Impact Categories-Utilisation of Midpoint categorisation) and ReCiPe Endpoint (H) (Utilisation of Endpoint categorisation). 


\section{Results and discussion}

\section{Production related}

In this section, results from a number of tests across the impact assessment methods presented above are provided. The analysis has shown that GWP impact of portion operations is almost double (4800 $\mathrm{kg} \mathrm{CO}_{2} \mathrm{Eq}$ ) that of whole birds $\left(2600 \mathrm{~kg} \mathrm{CO}_{2} \mathrm{Eq}\right)$. This due to the extra $20 \%$ downgrade and $30 \%$ extra removed material during portioning (back, skin, frame, etc.) needed to produce portions. Indeed, there is a much higher raw material requirement necessary to satisfy the demand for a tonne of portions than that of whole birds and it has a cascading effect on Portions Operations. For both types of operation, the major contributor to GWP is diet (Figure 3).

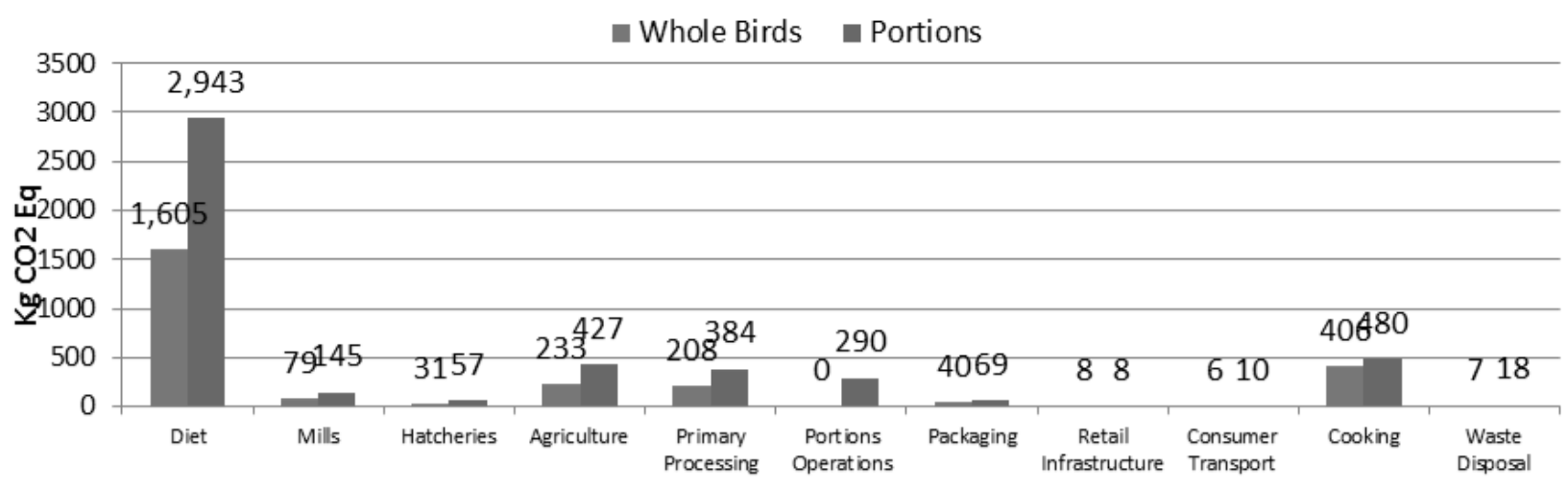

Figure 3: Whole Birds \& Portions 1t FU GWP Impact per System

In Figure 4, the proportional midpoint characterisation by system type is presented. For both Whole Birds and portions, diet is a significant impact across the assessment. However, it is worth observing the midpoint categories (Figure 5) in which diet is a $<50 \%$ contributor: Abiotic depletion; marine aquatic ecotoxicity; marine sediment ecotoxicity; and ionising radiation. All four of these midpoints show an increased contribution from agriculture, in particular, ionising radiation. The waste disposal and end-use cooking systems both vary between Whole Birds and portions. Abiotic depletion and GWP are more significantly affected by conventional oven use and are higher for the Whole Birds functional unit. Packaging waste disposal impact is greater for the portions $\mathrm{FU}$, showing a particularly significant contribution towards marine aquatic (21\%) and sediment (22\%) ecotoxicity midpoints. Closer analysis reveals that 
this is largely a result of the impact of the landfill element for the disposal of polypropylene (R-PP and PP).

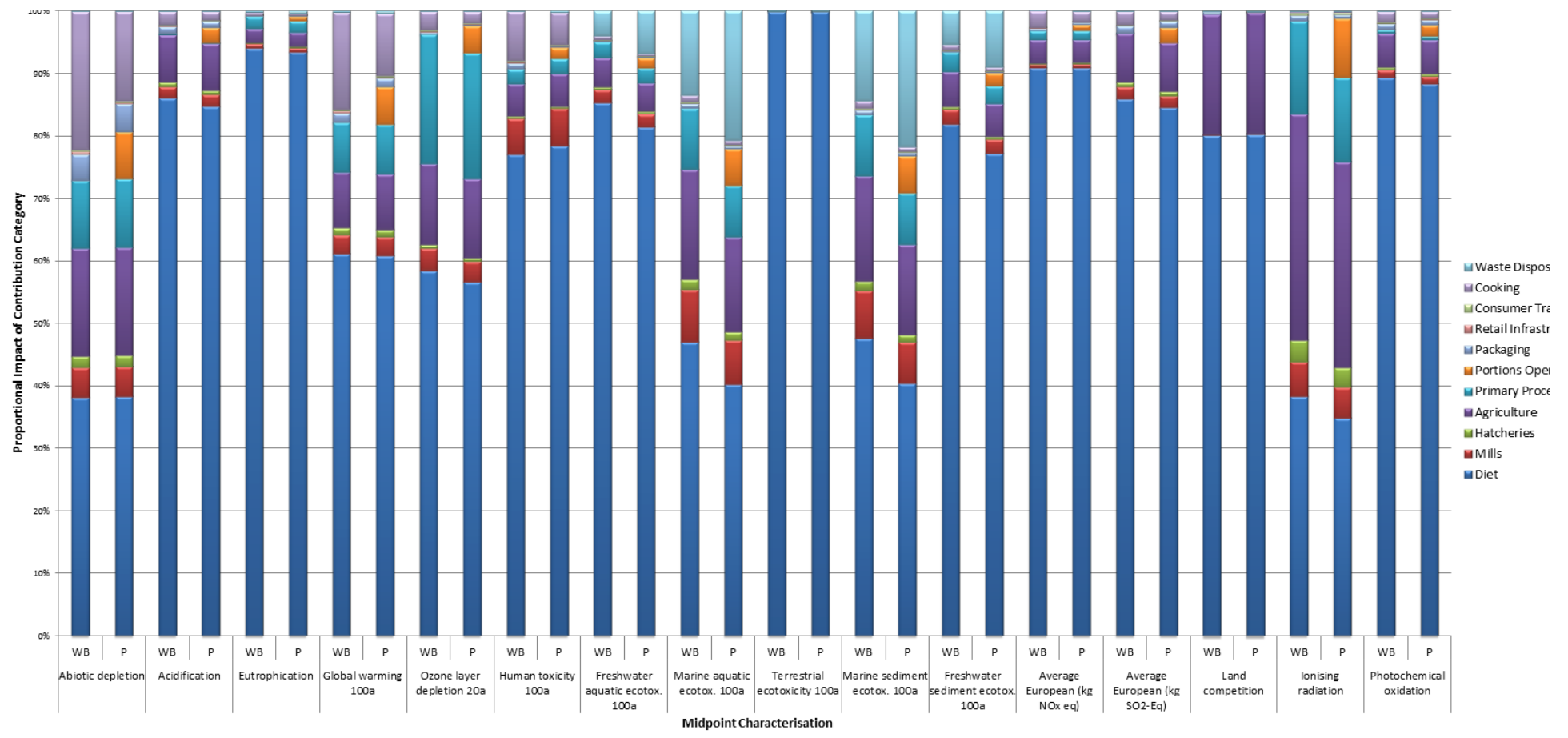

Figure 4. CML Proportional midpoint characterisation: Portions and Whole Birds (WB) comparison.

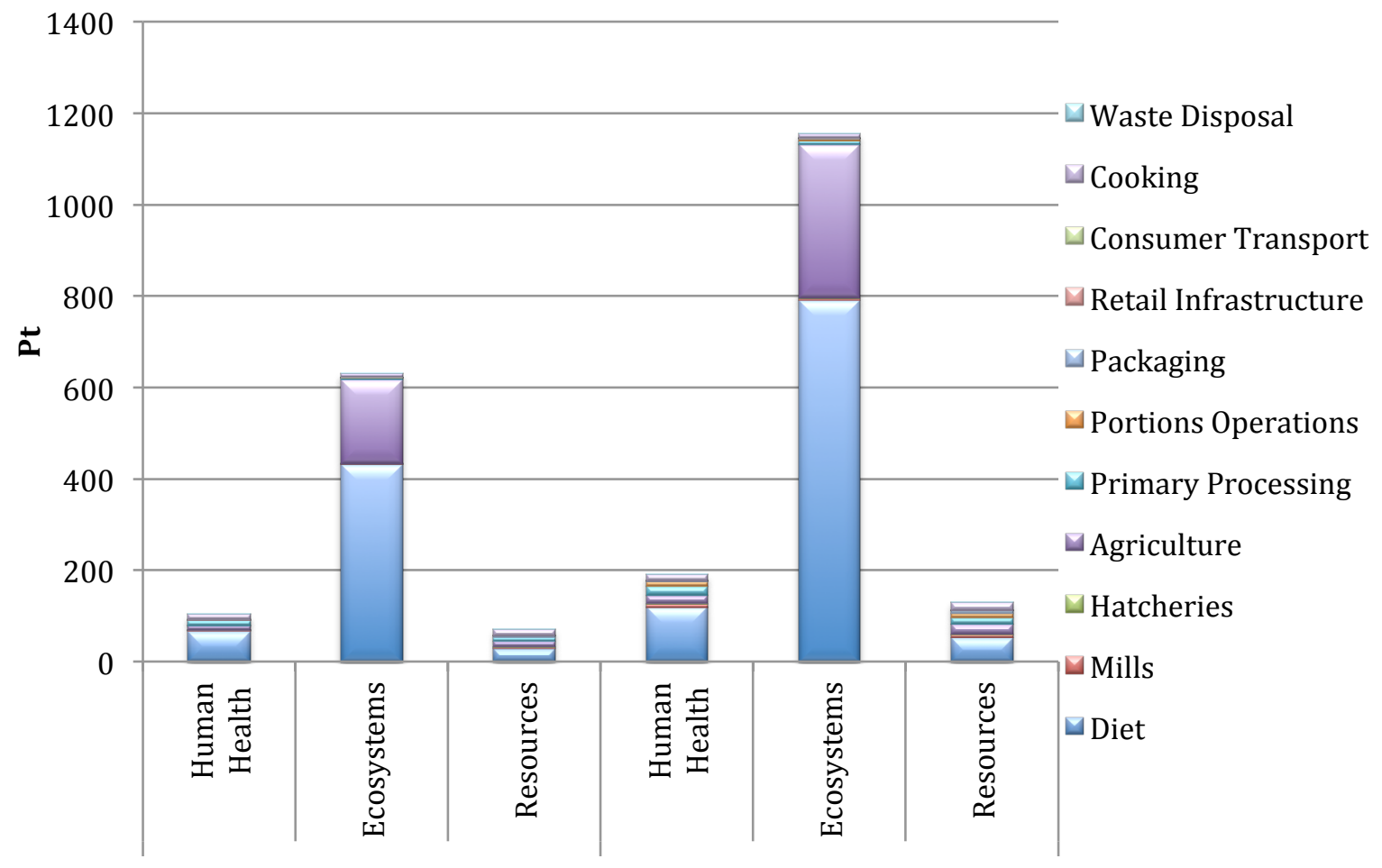


Figure 5: ReCiPe Endpoint system contribution comparison within endpoint categories.

Diet is also the largest to all three end point categories, especially to ecosystems damage. Agriculture is the second largest contributor, again for ecosystems. However, there is a greater contribution given to the remaining systems within resources. The human health category is still $62 \%$, but a greater contribution is found from cooking, primary processing, agriculture and mills systems than for other end points. The reason there is the similarity between contributions using this method is the weighting of the unit processes $>1 \%$, as they proportionally feature equally in functional units.

It is worth using the data to display how much impact each system has on each end point (Figure 6). For both diet and agriculture, the greatest impact is on ecosystems as would be expected, and as is highlighted by the previous methods employed. All other systems have an approximately 20\% ecosystems impact while varying between $40 \%$ and $60 \%$ between resources and human health. The packaging production and subsequent waste disposal scenario confirm logical assumptions. That is, there is a heavy resource demand on production and a heavy human health (and to an extent, ecosystems) impact attributed to waste disposal. However, it is surprising that the overall impact as a proportion to the total is relatively insignificant. 


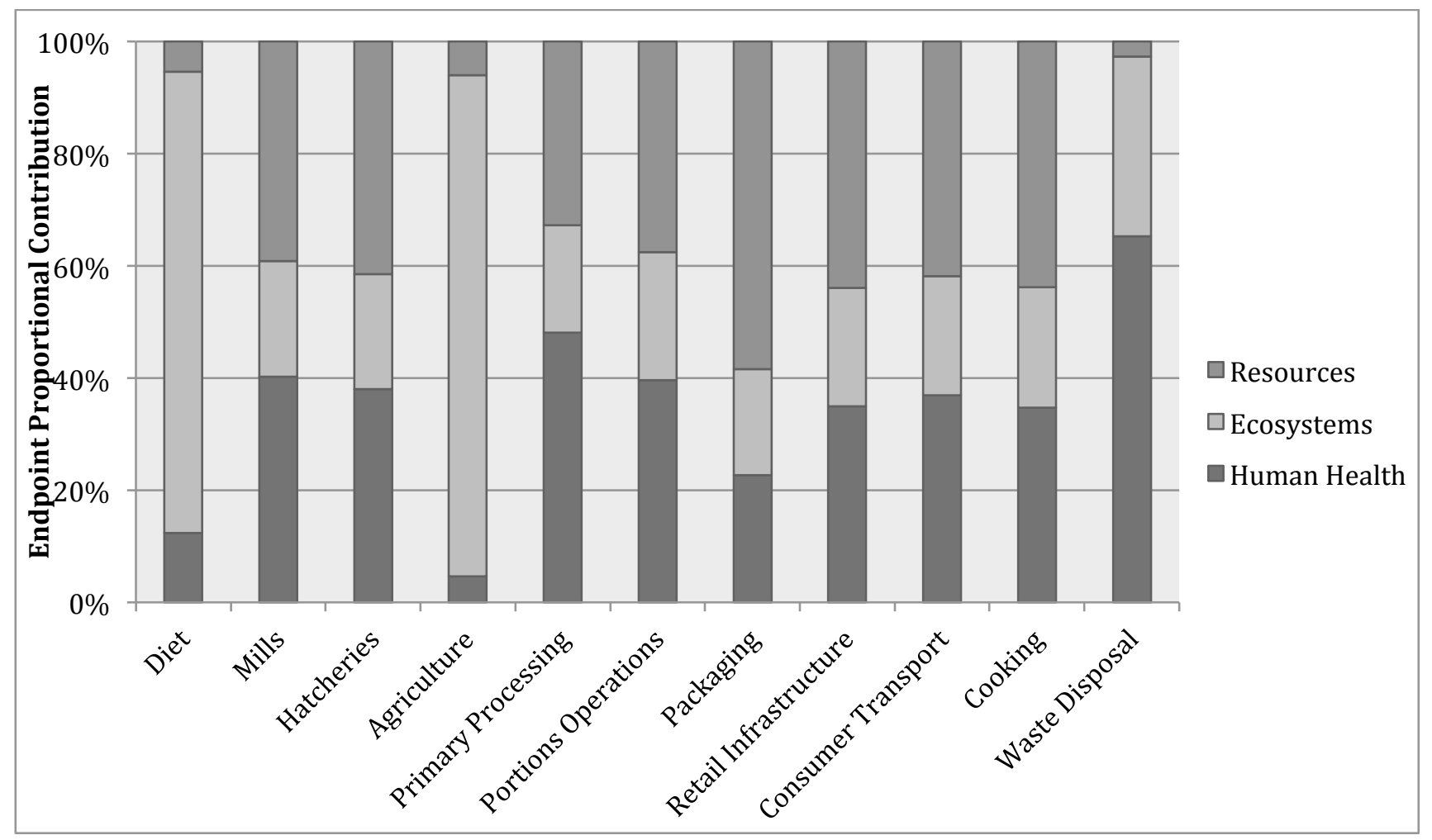

Figure 6. ReCiPe Endpoint total proportional impact per system by endpoints combined Functional Units

\section{Transport related}

The software model also allowed for simulating alterations with regard to the transport modes used. Research by Sim et al. (2007) has identified transport (and subsequently, the decision from where to source) as an important factor in determining the environmental sustainability of food supply chains. In this paper, despite the fact that we did not explore alternative sourcing scenarios (e.g. for feed), we try to provide an overview of the relative comparative impact of a range of transportation methods utilised across the supply chain, though not all directly by the company (Figures $\underline{7}$ and $\underline{8}$ ). By using a $100 \mathrm{tkm}$ benchmark, it is clear to assess the proportional environmental impact of each method, in this case, using the GWP and ReCiPe end point analysis methods. It is plain to see the additional impact which the utilisation of road transport produces, even more so using biofuel options on account of the associated agricultural ecosystem impact. 


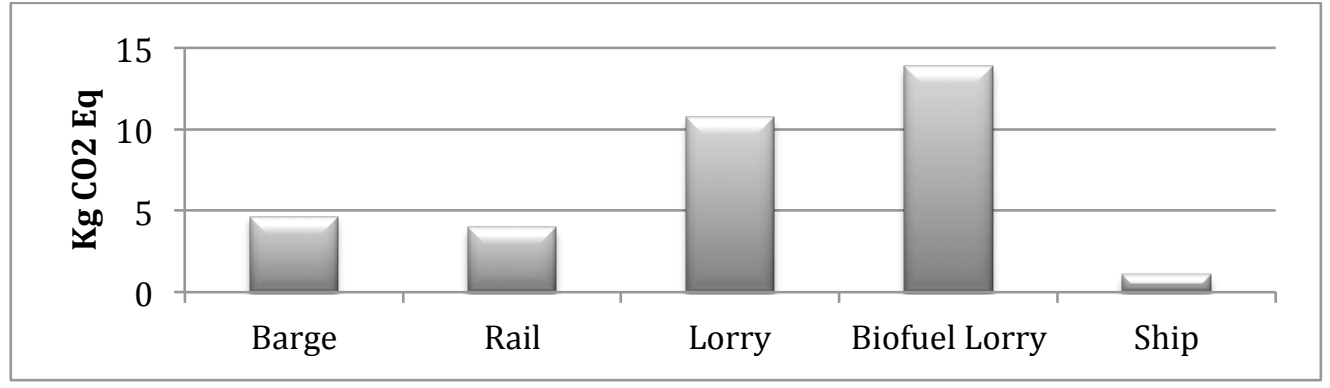

Figure 7: GWP 100a 100tkm $\mathrm{Kg} \mathrm{CO}_{2}$ Eq transportation methods comparison

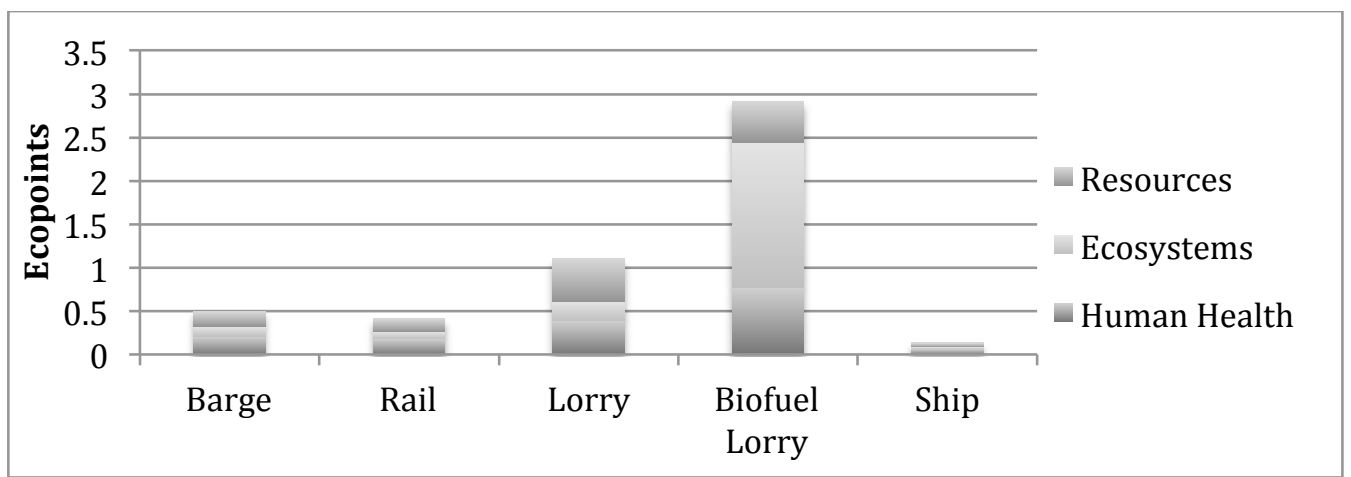

Figure 8. ReCiPe Endpoint - Ecopoints per 100 tkm transportation - methods comparison

\section{Comparison to other studies}

It is worth comparing the results of other chicken system LCA studies internationally. This LCA has been conducted on a specific company in contrast to many other studies, often using aggregate industry data. Other LCAs also focus on specific production systems such as free range or organic. The contrast between those systems and this company's process is an interesting one to consider. Compared studies were limited to those that were attributional; covered a large span of the supply chain; and in which primary data collection was sufficient to calculate GWP efficiently. Considering that none of the studies considered full life cycles with end-use scenarios, the results should be considered accordingly. In Table 3, an overall view of the key relevant studies is presented. All functional units are adjusted to $1 \mathrm{~kg}$ of live weight at the farm gate as per Weiedemann, McGahan, and Poad 2012. 
Table 3. Comparative LCA studies and GWP results (normalised).

\begin{tabular}{|l|c|l|c|}
\hline \multicolumn{1}{|c|}{ Author(s) } & Country & \multicolumn{1}{c|}{ Production System } & Kg CO$_{\mathbf{2}} \mathbf{~ E q}$ \\
\hline McCarthy et al. (2013) & $\begin{array}{c}\text { UK } \\
\text { this research) }\end{array}$ & $\begin{array}{l}\text { Conventional including processing \& } \\
\text { packaging Whole Birds. }\end{array}$ & 2.13 \\
\hline Cederberg et al. (2009) & Sweden & Farm Gate excluding processing & 1.35 \\
\hline Katajajuuri et al. (2008) & Finland & Conventional. Fillets to retail. & 1.3 \\
\hline Pelletier (2008) & USA & Farm Gate. Conventional. & 1.4 \\
\hline $\begin{array}{l}\text { Prudêncio da Silva et al. } \\
(2010)\end{array}$ & Brazil & $\begin{array}{l}\text { Conventional. Southern Brazil and } \\
\text { central-west Brazil production }\end{array}$ & $1.4-1.6$ \\
\hline Vergé et al. (2009) & Canada & Farm Gate. Conventional. & 1.0 \\
\hline Williams et al. (2006) & UK & Conventional, including processing & 3.2 \\
\hline Williams et al. (2006) & UK & $\begin{array}{l}\text { Free Range (non-organic) including } \\
\text { processing }\end{array}$ & 3.9 \\
\hline Williams et al. (2006) & UK & Organic including processing & 4.7 \\
\hline
\end{tabular}

The company under research appears to perform relatively well in comparison to other studies, particularly other UK production systems. Since 2006, when the Williams, Audsley, and Sandars (2006) study was undertaken, there has been an enormous level of poultry industry consolidation within the UK. The company itself has reduced the number of factories it operates since this point. It could be the case that greater consolidation affords the economies of scale to perform that much more efficiently and in doing so, reduce the environmental impact as others researchers suggest (Sorrell et al. 2004; Delmas and Pekovic 2013). The most surprising result is that of Williams' organic study showing over twice the impact of company's conventional operations. What is considered conventional is subjective and a more detailed analysis of these studies would be necessary to find specific points of comparison.

\section{Conclusions}

This paper presents implications for food (poultry in particular) production, sustainability and supply chain/ logistics practitioners. To begin with the former ones, results showed that the process of producing portions is considerably higher in total environmental impact than that of whole birds (4832 vs. $2662 \mathrm{~kg} \mathrm{CO} 2 \mathrm{Eq}$ ) and the outcome was the same for all three impact assessment methods utilised. This was concluded to be in large part due to the extra raw material required to produce the same mass into retail. It is interesting to note the differences encountered between the impact assessment methods. This is strikingly self-evident when examining the results of the 
transport comparison scenario. When broken down by end point category, it is clear to see the inflated ecosystems impact which biofuel is responsible for and the minimal impact of oceanic shipping.

A significant proportion of the total environmental impact is attributed to raw material production for the composite diet fed to the birds and thus difficult for a livestockproducing business to directly address. However, the study did, in part, influence concerted efforts to reduce the total business environmental impact. Examples of initiatives undertaken include: consolidation of Portions Operations reducing raw material and equipment vehicle movements by over 4000 full loads per year; installing lightweight axels to the feed mill fleet saving over 200 loads per year; initiation of a sustainable on-farm biomass generator project in Agriculture utilising a proportion of litter; installation of hot water generators with 99.7\% efficiency; and shop floor LED lighting with 10 -year life (saving $£ 20 \mathrm{k} \mathrm{pa}$ ).

From a logistics/supply chain management point of view, our research brings onto the table two main discussion points: the impact of a vertically integrated food supply chain on environmental performance and the use of consolidation as a means of reducing the environmental impact. Regarding vertical integration, despite the fact that it has been a well-known trend and practice in the food industry for many decades, particularly in the poultry sector, most of the incentives and benefits behind this trend have been linked to reduced transaction and quality control costs, supply variability minimisation, overall cost reductions or sometimes even positive influences on firm's innovation (Frank and Henderson1992; Hennessy 1996; Bhuyan 2005; Karantininis, Sauer, and Furtan 2010). On the contrary, the relationship between vertically integrated supply chains and environmental performance, to the best of authors' knowledge, has been neither discussed in the literature nor supported by empirical evidence. We believe that this is an area where further research is needed and that this research could serve as the basis for future comparisons. Similarly, for practitioners, there is a need to explore how consolidation could lead to environmental performance improvements and in particular to explore the trade-offs with service. 
Despite our efforts, the study is not without limitations. First, the findings are limited in terms of their external validity (generalisability) as they are based on a single case selected from a specific country and a specific sector. Second, the use of LCA as method to accurately calculate the environmental impact is very demanding and time consuming and also very much dependent on the existence of inventory data. In terms of future research, we believe that despite the disadvantages of LCA, there is always great scope for utilising the functionality of the LCA model to produce an unlimited range of supply chain sensitivity analysis and simulation. Further research, for example, might include alternative scenarios with respect to: litter disposal; supply chain configuration (e.g. procurement and transport options); and packaging (waste and production). Finally, given the characteristics of the poultry sector: integrated supply chain, mass produced product and consumption changing patterns towards more pre-cooked or prepared food, the findings have potentially wide implications (Yakovleva and Flynn 2004).

\section{Acknowledgements}

The authors would like to express their thanks to the Faccenda Group Ltd for providing the relevant data.

\section{References}

Andersson, K. 2000. "Lca of Food Products and Production Systems." The International Journal of Life Cycle Assessment 5 (4): 239-248. doi: 10.1007/BF02979367.

Baumann and Tillman. 2004. The Hitch Hiker's Guide to LCA, Studentlitteratur, 2004.

Bengtsson, J., and J. Seddon. 2012. "Cradle to Retailer or Quick Service Restaurant Gate Life Cycle Assessment of Chicken Products in Australia." Journal of Cleaner Production 41: 291-300. doi:10.1016/j.jclepro.2012.09.034

Bhuyan, S. 2005. “An Empirical Evaluation of Factors Determining Vertical Integration in US Food Manufacturing Industries.” Agribusiness $21 \quad$ (3): 429-445. doi: 10.1002/agr.20056

BPC. 2013. Structure of the British Poultry Council. Accessed June 21, 2013.http://www.britishpoultry.org.uk/?page_id=1620http://www.britishpoultry. org.uk/?page_id=1620 
Browne, M., C. Rizet, S. Anderson, J. Allen, and B. Keïta. 2005. "Life Cycle Assessment in the Supply Chain: A Review and Case Study." Transport Reviews 25 (6): 761-782. doi:10.1080/01441640500360993

Castellini, C., A. Boggia, C. Cortina, A. Dal Bosco, L. Paolotti, E. Novelli, and C. Mugnai. 2012. "A Multicriteria Approach for Measuring the Sustainability of Different Poultry Production Systems." Journal of Cleaner Production 37: 192-201. doi: 10.1016/j.jclepro.2012.07.006

Cederberg, C., U. Sonesson, M. Henriksson, V. Sund, and J. Davis. 2009. Greenhouse Gas Emissions from Swedish Production of Meat, Milk and Eggs 1990 and 2005. SIKInstitutet för livsmedel och bioteknik.

Davis, J., and U. Sonesson. 2008. "Life Cycle Assessment of Integrated Food Chains - A Swedish Case Study of two Chicken Meals." The International Journal of Life Cycle Assessment 13 (7): 574-584. doi: 10.1007/s11367-008-0031-y

Delmas, M. A., and S. Pekovic. 2013. Resource Efficiency Strategies and Market Conditions." Long Range Planning. no. 0.

European Commission. 2011. A Resource-Efficient Europe - Flagship Initiative Under the Europe 2020 Strategy. Communication from the Commission to the European Parliament, the Council, the European Economic and Social Committee and the Committee of the Regions. Brussels, 26.1.2011, COM(2011) 21.

FA0. 2006. Livestock's Long Shadow: Environmental Issues and Options. In Nations, Rome. Accessed June 26 , 2013. https://www.globalmethane.org/expo_china07/docs/postexpo/ag_gerber.pd $\mathrm{f}$

FA0. 2011. Global Food Losses and Food Waste: Extent, Causes and Prevention. Food and Agriculture Organization of the United Nations Report, Rome.

FoodDrinkEurope. 2012a. Data \& Trends of the European Food and Drink Industry 2011. Accessed September 15, 2013. http://www.fooddrinkeurope.eu/publication/data-trends-of-the-europeanfood-and-drink-industry-2011/

FoodDrinkEurope. 2012b. Environmental Sustainability Vision Towards 2030. Accessed September

2013. http://www.fooddrinkeurope.eu/publication/fooddrinkeurope-launchesenvironmental-sustainability-vision-for- 
2030/http://www.fooddrinkeurope.eu/publication/fooddrinkeurope-launchesenvironmental-sustainability-vision-for-2030/

Frank, S. D., and D. R. Henderson. 1992. "Transaction Costs as Determinants of Vertical Coordination in the US Food Industries." American Journal of Agricultural Economics 74 (4): 941-950. doi: 10.2307/1243192

Harris, S., and V. Narayanaswamy. 2009. Review of Australian and International Agricultural Life Cycle Assessment Examples. Report Prepared for Rural Industries Research and Development Corporation, Canberra.

Hennessy, D. A. 1996. "Information Asymmetry as a Reason for Food Industry Vertical Integration."American Journal of Agricultural Economics 78 (4): 1034-1043. doi: $10.2307 / 1243859$

ISO. 2006. 14044: Environmental Management - Life Cycle Assessment - Requirements and Guidelines. International Organization for Standardization.

Karantininis, K., J. Sauer, and W. H. Furtan. 2010. "Innovation and Integration in the AgriFood Industry." Food Policy 35 (2): 112-120. doi: 10.1016/j.foodpol.2009.10.003

Katajajuuri, J., J. Grönroos, and K. Usva. 2008. Environmental Impacts and Related Options for Improving the Chicken Meat Supply Chain. 6th International Conference on LCA in the Agri-Food Sector, Zurich, November.

Kist, L. T., S. E. Moutaqi, and Ê. L. Machado. 2009. "Cleaner Production in the Management of Water use at A Poultry Slaughterhouse of Vale do Taquari, Brazil: A Case Study." Journal of Cleaner Production $17 \quad$ (13): 1200-1205. doi: 10.1016/j.jclepro.2009.04.006

Leinonen, I., A. G. Williams, J. Wiseman, J. Guy, and I. Kyriazakis. 2012. "Predicting the Environmental Impacts of Chicken Systems in the United Kingdom Through a Life Cycle Assessment: Broiler Production Systems." Poultry Science 91 (1): 8-25. doi: $10.3382 / p s .2011-01634$

Nemetz, P. 2007. Sustainable Resource Management, Reality or Illusion? Northampton, MA: Edward Elgar. Neves, M. F. 2011. The Future of Food Business: The Facts, the Impacts, the Acts. Singapore: World Scientific.

ONS. 2011. Summary: UK Population Projected to Reach 70 Million by mid2027. In Statistics, O. F. N. ed. Accessed June 26, 2013. http://www.ons.gov.uk/ons/dcp29904_240697.pdf 
Pelletier, N. 2008. "Environmental Performance in the us Broiler Poultry Sector: Life Cycle Energy use and Greenhouse gas, Ozone Depleting, Acidifying and Eutrophying Emissions." Agricultural Systems98 (2): 67-73. doi: 10.1016/j.agsy.2008.03.007

Prudêncio Da Silva, V., H. M. G. Van Der Werf, A. Spies, and S. R. Soares. 2010. "Variability in Environmental Impacts of Brazilian Soybean According to Crop Production and Transport Scenarios."Journal of Environmental Management 91 (9): 1831-1839. doi: 10.1016/j.jenvman.2010.04.001

Rabobank. 2012. What Next for the UK Poultry. Rabobank Industry Note \#298 - January 2012. Accessed June 20, 2013. http://www.farminguk.com/KnowledgeCentre/Downloads/What-Next-forUK-Poultry-_177.html

Sim, S., M. Barry, R. Clift, and S. J. Cowell. 2007. "The Relative Importance of Transport in Determining an Appropriate Sustainability Strategy for Food Sourcing." The International Journal of Life Cycle Assessment 12 (6): 422-431.

Sonesson, U., J. Berlin, and F. Ziegler. 2010. Environmental Assessment and Management in the Food Industry: Life Cycle Assessment and Related Approaches. Cambridge: Woodhead.

Sorrell, S., E. O'malley, J. Schleich, and S. Scott. 2004. The Economics of Energy Efficiency: Barriers to Cost-Effective Investment. Cheltenham: Edward Elgar.

Tan, M. Q. B., R. B. H. Tan, and H. H. Khoo. 2012. Prospects of Carbon Labelling - A Life Cycle Point of View. Journal of Cleaner Production, no. 0.

Tillman, A. M. 2010. "Methodology for Life Cycle Assessment." In Environmental Assessment and Management in the Food Industry: Life Cycle Assessment and Related Approaches, edited by U. Sonesson, J. Berlin, and F. Ziegler, 59-82. Cambridge: Woodhead.

Tongpool, R., N. Phanichavalit, C. Yuvaniyama, and T. Mungcharoen. 2012. "Improvement of the Environmental Performance of Broiler Feeds: A Study via Life Cycle Assessment." Journal of Cleaner Production 35: 16-24. doi: 10.1016/j.jclepro.2012.05.007

Vergé, X. P. C., J. A. Dyer, R. L. Desjardins, and D. Worth. 2009. "Long-term Trends in Greenhouse gas Emissions from the Canadian Poultry Industry." The Journal of Applied Poultry Research 18 (2): 210-222. doi: 10.3382/japr.2008-00091 
Virtanen, Y., S. Kurppa, M. Saarinen, J.-M. Katajajuuri, K. Usva, I. Mäenpää, J. Mäkelä, J. Grönroos, and A. Nissinen. 2011. "Carbon Footprint of Food - Approaches from National Input-Output Statistics and a LCA of a Food Portion." Journal of Cleaner Production 19 (16): 1849-1856. doi:10.1016/j.jclepro.2011.07.001

Ward, C. E. 1997. Vertical Integration Comparison: Beef, Pork, and Poultry. Paper submitted to the Western Agricultural Economics Association. Accessed June 26, 2013.http://ageconsearch.umn.edu/bitstream/35759/1/waeasp21.pdf

Wiedemann, S., E. McGahan, and G. Poad. 2012. Using Life Cycle Assessment to Quantify the Environmental Impact of Chicken Meat Production. Final Report, RIRDC Project No PRJ-004596. Rural Industries Research and Development Corporation., Barton, ACT.

Williams, A., E. Audsley, and D. Sandars. 2006. Determining the Environmental Burdens and Resource Use in the Production of Agricultural and Horticultural Commodities: Defra Project Report is0205. Accessed June 26, 2013. http://randd.defra.gov.uk/Default.aspx

Wognum, P. M. (Nel), H. Bremmers, J. H. Trienekens, J. G. A. J. van der Vorst, J. M. Bloemhof.2011. "Systems for Sustainability and Transparency of Food Supply Chains - Current Status and Challenges." Advance Engineering Informatics 25 (1): 65-76. doi: 10.1016/j.aei.2010.06.001

WT0. 2009. International Trade Statistics 2009. Accessed September 16, 2012.http://www.wto.org/english/res_e/statis_e/its2009_e/its09_toc_e.htmhttp:// www.wto.org/english/res_e/statis_e/its2009_e/its09_toc_e.htm

Yakovleva, N., and A. Flynn. 2004. "Innovation and Sustainability in the Food System: A Case of Chicken Production and Consumption in the UK." Journal of Environmental Policy and Planning 6 (3-4): 227-250. doi: 10.1080/1523908042000344096

Yin, R. K. 2003. Case Study Research: Design and Methods. Thousand Oaks, CA: Sage. 